\title{
Is remdesivir the therapeutic answer for COVID-19: a review of current knowledge
}

\author{
Marya Ahsan ${ }^{1 *}$, Ayaz Khurram Mallick²
}

\author{
${ }^{1}$ Department of Pharmacology, College of Medicine, Al-Imam Mohammad Ibn Saud Islamic University, Riyadh, \\ Kingdom of Saudi Arabia \\ ${ }^{2}$ Department of Clinical Biochemistry, College of Medicine, King Khalid University, Abha, Kingdom of Saudi Arabia
}

Received: 26 June 2020

Accepted: 31 July 2020

\section{*Correspondence:}

Dr. Marya Ahsan,

Email: marya_ahsan@yahoo.co.in

Copyright: (C) the author(s), publisher and licensee Medip Academy. This is an open-access article distributed under the terms of the Creative Commons Attribution Non-Commercial License, which permits unrestricted non-commercial use, distribution, and reproduction in any medium, provided the original work is properly cited.

\begin{abstract}
As the world races to find the solution to the COVID-19 pandemic, an investigational agent which has triggered worldwide interest is remdesivir. Though failing clinical trials for treatment of Ebola virus disease, remdesivir has shown efficacy in numerous viral studies involving SARS-CoV-2. Reports from compassionate use of remdesivir in hospitalized patients of COVID-19 have been promising. But the real picture about the safety and efficacy of remdesivir can only be known after completion of randomized clinical trials. In this review, we aim to highlight the salient features of pharmacokinetics and pharmacodynamics of remdesivir known so far and its plausible role in management of COVID-19. We searched the PubMed database and Google Scholar for published literature using the key words: remdesivir, human coronavirus, novel coronavirus, COVID-19, SARS-CoV 2, mechanism of action, pharmacokinetics, pharmacodynamics and compassionate use till $1^{\text {st }}$ May 2020. The U. S. national library of medical trials registry was searched for ongoing trials with remdesivir among patients of COVID-19. Remdesivir is a prodrug of a nucleoside Analog that inhibits RNA replication by binding to viral RNA dependent RNA polymerase. It is being employed in many global phase-3 clinical trials for evaluating the efficacy and safety of the drug in patients of COVID-19.
\end{abstract}

Keywords: SARS-Cov-2, COVID-19, Remdesivir, RNA-dependent RNA polymerase

\section{INTRODUCTION}

The coronavirus disease - 2019 (COVID-19) pandemic has posed unprecedented challenge to health systems globally and has wide social and economic ramifications. ${ }^{1}$ COVID-19 is caused by the 2019 - novel coronavirus designated as severe acute respiratory syndrome - coronavirus 2 (SARS-CoV2) belonging to the beta coronavirus genera of the family coronaviridae. ${ }^{2}$ The current pandemic presents with diverse severity ranging from asymptomatic carriers to mild respiratory tract infection or pneumonia and complications like acute respiratory distress, multisystem organ failure and death. ${ }^{3}$ Published research has recorded an overall case fatality rate ranging from $2-3.4 \% .^{3,4}$ At the time of writing the article almost six million people have been infected, resulting in more than 360,000 deaths globally. ${ }^{5}$

Global research efforts are under way in search for vaccines against COVID-19 or effective treatment in order to alleviate human suffering. Currently, therapy only consists of supportive care while a variety of investigational agents and repurposing of approved drugs is being explored. ${ }^{6-9}$ Evidence from pre-clinical and clinical studies prompted the World Health Organization (WHO) to launch an international randomized trial, the solidarity trial, to explore four treatment options in COVID-19: remdesivir, lopinavir/ritonavir, 
lopinavir/ritonavir with interferon beta 1a, and chloroquine or hydroxychloroquine. ${ }^{9}$ Remdesivir is a broad-spectrum antiviral. ${ }^{6,10-13}$ It was initially developed by Gilead sciences, Inc. as treatment for Ebola, but the randomized trial with remdesivir was stopped midway as other treatment options were found to be superior. ${ }^{10,14}$ However, a case-report about clinical improvement within one day following compassionate use of intravenous remdesivir for the first COVID-19 patient in the United States has triggered great interest in the antiviral. ${ }^{15}$

With this review we plan to describe the SARS-CoV-2 and explain why remdesivir acts against SARS-CoV-2, describe its pharmacokinetics and pharmacodynamics and highlight salient features of clinical trials exploring the role remdesivir as a treatment option for COVID-19.

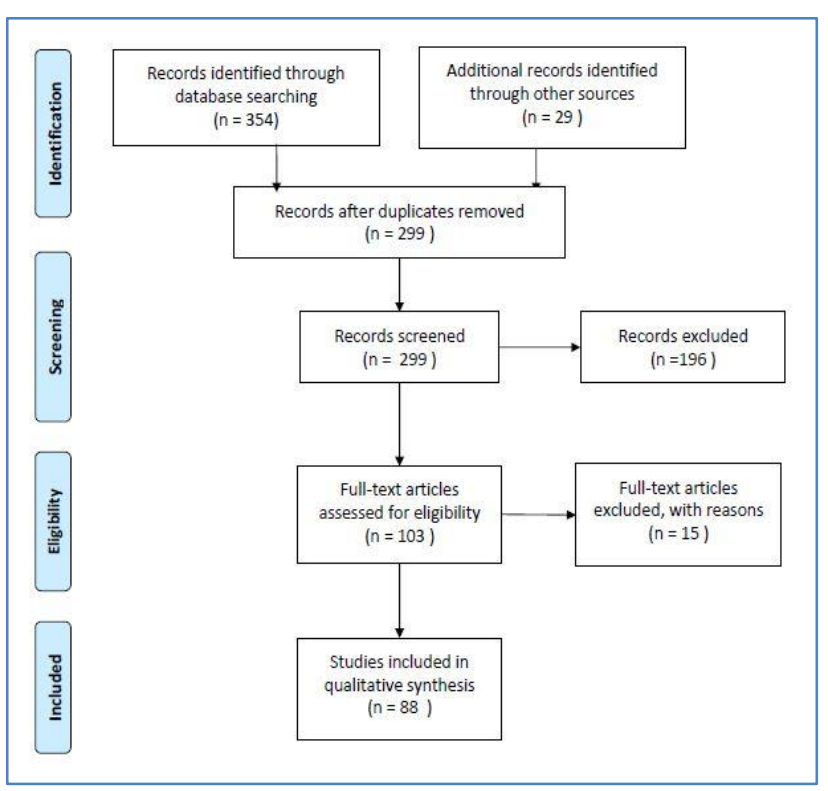

Figure 1: Prisma flow chart for selection of studies for review.

For this qualitative review, we followed preferred reporting items for systematic reviews and meta-analyses guidelines (PRISMA guidelines). The Prisma flowchart for the study is given in Figure 1. The PubMed database and Google Scholar were screened with the keywords: remdesivir, human coronavirus, novel coronavirus, COVID-19, SARS-CoV 2, mechanism of action, pharmacokinetics, pharmacodynamics and compassionate use till $1^{\text {st }}$ May 2020. The U. S. national library of medical trials registry was also searched with the keywords remdesivir and COVID-19. Endnote software was used for extracting articles from the database. Rayyan QCRI was used for screening of title and abstract. Full texts of selected articles were further screened for inclusion in the review. Only articles exploring the drug targets of SARS-CoV-2 and those describing the role of remdesivir in COVID-19 such as the mechanism of action, pharmacokinetics, resistance and adverse effects were included. current ongoing studies evaluating remdesivir in the treatment of COVID19 were also included. Articles exploring the efficacy of remdesivir in other viral infections other than COVID-19 were excluded from the final review.

\section{HUMAN CORONAVIRUS}

The coronoviruses are enveloped, positive sense RNA viruses composed of four genera: alpha, beta, gamma and deltacoronaviruses. ${ }^{11}$ The alpha and beta genera are known to cause diseases in humans - human CoV. Before the pandemic, there were six known human coronaviruses. The four common human coronavirus strains causing mild respiratory tract infections in humans are HKU1, NL63, 229E and OC43. ${ }^{16}$ However, they can cause severe disease in elderly and people with underlying respiratory conditions, at times requiring hospitalization and can even cause acute respiratory distress syndrome. ${ }^{17}$ The other two coronaviruses which emerged over the last two decades are SARS-CoV and MERS-CoV. Both caused severe and even fatal lower respiratory tract disease. ${ }^{18}$ SARS-CoV-2 has $79 \%$ similarity with SARS-CoV and 50\% with MERS-CoV. ${ }^{19}$

Human coronaviruses are characterized by two sets of proteins structural proteins and non-structural proteins. The structural proteins include the hall mark spike protein $(\mathrm{S})$, nucleocapsid $(\mathrm{N})$, matrix $(\mathrm{M})$ and envelope $(\mathrm{E})$. The non-structural proteins are proteases (nsp3 and nsp5) and RNA dependent RNA polymerase (nsp 12). ${ }^{20}$ The multisubunit complex of non-structural proteins is vital for the replication of the virus. ${ }^{21}$ It is often the target for drug development against RNA viruses. ${ }^{22}$ Studies have shown that the active site of RNA dependent RNA polymerase (RdRp) in SARS-CoV 2 is nsp 12. ${ }^{21}$ The active site is highly conserved. ${ }^{23}$ However, nsp7 and nsp 8 are required as accessory factors for nsp 12 to exert its template binding activity and processivity. Thus, the RdRp complex consists of nsp7-nsp8-nsp12 assembly. ${ }^{24,25}$

\section{SARS-COV-2 LIFE CYCLE}

The $\mathrm{S}$ protein (spikes) on the virus attach and bind to the angiotensin-converting enzyme-2 (ACE-2) receptor on the cell surface. ${ }^{26,27}$ After binding, the virus enters the human cell via endocytosis. Inside the mature endosome, acid proteases cleave the $\mathrm{S}$ protein, allowing membrane fusion and release of viral genome. ${ }^{28}$ The viral genome is translated into polyproteins which are cleaved by viral proteases to release functional proteins. The viral RNA is replicated by the viral replication complex. Structural proteins and viral RNA are assembled to form new infectious virions which are released by exocytosis. ${ }^{24-28}$

\section{MECHANISM OF ACTION}

Remdesivir is broad-spectrum antiviral and effective against a host of RNA viruses such as Ebola virus, Nipah virus, Marburg virus, respiratory syncytial virus, Hendra virus SARS-CoV and MERS-CoV..$^{6,10-13}$ It is a 
monophosphoramidate prodrug of an adenosine analog. 6,13 Following diffusion inside the cell, it is metabolized by a series of steps to liberate the monophosphate form. Monophosphates are highly polar and are trapped inside the cell. It is then converted to an active triphosphate form in the cells. ${ }^{29}$ The active form (triphosphate form) of remdesivir competes with ATP for incorporation into the viral RNA. This results in premature termination of strand elongation. ${ }^{12,13}$ However, coronaviruses have exonucleases which have proofreading ability and are able to excise the faulty nucleoside analog. ${ }^{30}$ This is the reason for resistance to majority of the nucleoside Analogs. Remdesivir however is able to maintain sensitivity as it outpaces the proofreading ability of the exonuclease. Hence, it interferes with RNA transcription by inhibiting viral RNA polymerase and evades proofreading by exoribonuclease, leading to a decrease in viral RNA production. Study conducted on a mutant murine hepatitis virus lacking the proofreading mechanism showed increased sensitivity to remdesivir. ${ }^{30}$ In addition, remdesivir is 500 times more selective for viral RNA polymerase than human RNA polymerases. Human RNA polymerase II and mitochondrial RNA polymerase are not inhibited by remdesivir. ${ }^{12}$

\section{RESISTANCE}

Resistance to remdesivir can develop as a result of mutation in the RdRp nsp 12 (F476L and V553L) as seen in case of murine hepatitis virus. ${ }^{30}$ Moreover, as the proof-reading mechanism is an important feature of RNA transcription, it is also postulated that mutations that increase the efficacy of the proof-reading mechanism can also make the virus resistant to remdesivir. However, studies in infected cell cultures showed that the mutant strains were rapidly replaced by the wild strain of the virus, thus retaining sensitivity. ${ }^{30}$

\section{PHARMACOKINETICS}

Remdesivir is available in a stable lyophilized formulation which does not require cold chain before consumption. It is given as an intravenous infusion in a loading dose of $200 \mathrm{mg}$ over 30 minutes on day 1 in adults (body weight $\geq 40 \mathrm{kgs}$ ) followed by maintenance dose of $100 \mathrm{mg}$ infusion over 30 minutes per day from day 2-10. Therapy is continued for 10 days in total. Treatment regimens of 5 days duration are also being evaluated in clinical trials. Paediatric patients (body weight $<40 \mathrm{kgs}$ ) require remdesivir in loading dose of 5 $\mathrm{mg}$ per $\mathrm{kg}$ body weight on day 1 . Maintenance dose for paediatric patients is $2.5 \mathrm{mg} / \mathrm{kg} /$ day for the remaining duration of therapy. ${ }^{31}$

Pharmacokinetic studies in non-human primates (rhesus monkeys) have shown that an intravenous dose of $10 \mathrm{mg} / \mathrm{kg}$ of remdesivir resulted in a short half-life of 0.39 hours for the parent drug. But the active drug remained persistently in peripheral blood mononuclear cells with a $\mathrm{t}^{1 / 2}$ of 14 hours. This level was effective against Ebola virus infection. ${ }^{10}$ In healthy cynomolgus monkeys, remdesivir distributes widely to sanctuary sites such as genital tract, eyes and even brain. ${ }^{10}$

Pharmacokinetic data from clinical studies revealed doselinear pharmacokinetics following single dose, two hours infusion remdesivir infusion (dose 3-225 mg). Timelinear pharmacokinetics was observed with repeated once-daily 1-hour infusions of $150 \mathrm{mg}$ remdesivir for 14 days. Administration over a shorter time interval of 30 mins was found to be a more effective method of dosing for maximizing the intracellular concentration of active drug while long intracellular $t^{1} / 2$ of active drug supports once daily dosing. Accumulation ratio of 2.7-3.5 times of the active metabolite supports giving a loading dose of remdesivir in acutely infected patients followed by maintenance doses. ${ }^{31}$

\section{EFFICACY OF REMDESIVIR AGAINST SARS- COV-2}

Most of the studies of remdesivir have been done on genetically related viruses. However, as there is increased genetic heterogenicity even within the human strains, it remains to be seen if efficacy against similar viruses translates into efficacy against SARS-CoV-2. ${ }^{32}$

Remdesivir was tested in VeroE6 cells infected with nCoV-2019BetaCoV/Wuhan/WIV04/2019. Effect on cytotoxicity, virus yield and infection rates of 2019nCoVs were assayed. Remdesivir potently blocked virus infection at low-micromolar concentration and reported a percentage of inhibition on linear scale as EC50 $=0.77$ $\mu \mathrm{M} .{ }^{33}$ Another study in VeroE6 cells infected with SARSCoV-2 virus, beta CoV/Hong Kong/VM20001061/2020, reported EC50 as $23.15 \mu \mathrm{M}$ when viral load was fitted on logarithmic scale. ${ }^{34}$

\section{COMPASSIONATE USE OF REMDESIVIR}

When no proven effective treatment exists, individual patients may be offered experimental interventions after informed consent on compassionate grounds in case of emergency outside clinical trials. Human data on remdesivir use for COVID-19 started pouring in following compassionate use of the drug in critical patients. A case report in NEJM illustrated that the first COVID-19 patient in US, a 35 years old male, who developed pneumonia was treated with intravenous remdesivir on the $7^{\text {th }}$ day of hospitalization (illness day 11). ${ }^{15}$ His clinical condition improved on the $8^{\text {th }}$ day (illness day 12). Oxygen saturation improved to $94-96 \%$ without supplemental oxygen and bilateral lower-lobe rales disappeared in addition to improvement in appetite. No adverse effects were reported following remdesivir use. $^{15}$

A preliminary report in a small cohort of patients $(n=53)$ spanning across US, Canada, Europe and Japan who were 
severely ill with COVID-19 (oxygen saturation $\leq 94 \%$ ) and treated with remdesivir for 10 days, showed clinical improvement in $68 \%$ patients. ${ }^{35}$ However, the cohort study did not collect viral load data in response to remdesivir treatment. Though non-clinical toxicology studies have detected renal changes, there was no evidence of nephrotoxicity in this cohort. Mild-tomoderate elevation in ALT, AST, or both were detected. But whether it was due to COVID-19 or remdesivir use could not be confirmed as liver dysfunction is common in COVID-19 patients. ${ }^{35}$ The safety profile of remdesivir in COVID-19 needs to be assessed through placebocontrolled clinical trials.

\section{TRIALS CURRENTLY INVESTIGATING THE USE OF REMDESIVIR IN COVID-19}

Remdesivir is not FDA approved. The intravenous antiviral is being investigated in a number of trials as a treatment option for COVID-19. In this review we have highlighted salient features of some of the current clinical trials.

\section{Solidarity trial}

The WHO has started enrolling patients in more than 100 countries around the globe to reduce time taken required for results by $80 \%$. It aims to identify the most effective treatment among - remdesivir, hydroxychloroquine/chloroquine, lopinavir-ritonavir, lopinavir-ritonavir plus interferon beta-1a. The advantage of such a global trial overcomes the drawbacks of small trials not generating strong evidence. Adults with confirmed COVID-19, who consent for the treatment are electronically allocated to one of the treatment arms of the study or the local standard of care. The trial aims to collect information about which study drugs were given and for how many days, whether ventilation or intensive care was required and for how long, when the patient is discharged or dies. Information is also collected regarding the underlying conditions and the severity of illness at entry. ${ }^{9}$

\section{Discovery trial}

It is a multicentric adaptive, open-label, randomized trial being carried out in different centres in Europe. It aims to evaluate five arms: standard of care alone or standard of care with either of the following: remdesivir or hydroxychloroquine or lopinavir/ritonavir or lopinavir/ritonavir along with interferon beta 1a. The primary objective of the study is clinical status of the patient on a 7 points ordinal scale on day 15 . The study will enrol 3100 patients and is expected to be completed by March $2023 .{ }^{36}$

\section{Adaptive COVID-19 treatment trial (ACTT)}

It is a phase 3 multicentric trial, randomized, doubleblinded, placebo-controlled trial being carried out at more than 100 centres globally to evaluate the safety and efficacy of investigational therapies. ${ }^{37}$ Patients receiving remdesivir will be given $200 \mathrm{mg}$ of the drug intravenously on day 1 , followed by $100 \mathrm{mg}$ daily for the remaining 9 days. Total duration of the treatment is 10 days. The current primary outcome of the trial as described in the U. S. national library of medicine clinical trials registry is the day of recovery (upto 29 days). Day of recovery is defined as the first day on which one of the three categories on an ordinal scale are met by the patient as given in Table 1. As per a new release in the end of April, preliminary data from this national institute of allergy and infectious diseases sponsored trial of 800 patients of advanced COVID-19, showed that patients who received remdesivir left the hospital earlier (average 11 days) in comparison to the control group (average 15 days). ${ }^{38}$ The trial began in February 2020 and is expected to be completed by April 2023. ${ }^{37}$

Table 1: Current primary outcome for the U.S. National Institute of Health sponsored clinical trial (NCT04280705) on remdesivir; first day on which one of the three criteria are met.

\begin{tabular}{|ll|}
\hline Criteria & Description \\
\hline $\mathbf{1}$ & $\begin{array}{l}\text { Patient is hospitalized, but does not } \\
\text { require supplemental oxygen/ongoing } \\
\text { medical care }\end{array}$ \\
\hline $\mathbf{2}$ & $\begin{array}{l}\text { Patient is not hospitalized, but activities } \\
\text { are limited and/or requires home oxygen }\end{array}$ \\
\hline $\mathbf{3}$ & $\begin{array}{l}\text { No hospitalization, no limitation of } \\
\text { activities }\end{array}$ \\
\hline
\end{tabular}

\section{Gilead sponsored trials}

Besides the above trials, Gilead is sponsoring phase 3 clinical trials of remdesivir in the USA comparing 5 days, 10 days and standard of care treatments: NCT04292899 and NCT04292730. ${ }^{39,40}$ As per the U. S. national library of medicine clinical trials registry both are open-labelled randomized trials which will enrol an estimated 6000 and 1600 patients respectively and are expected to be completed in May 2020. The primary outcomes of the above studies are the odds ratio for clinical improvement on day 14 and day 11 respectively. A 7 points ordinal scale is used for clinical assessment of the patient, where $1=$ death and $7=$ not hospitalized.

\section{WHO NOR (Norwegian) COVID-19 study}

This Oslo University Hospital sponsored multi-centric trial will follow WHO core points but has additional safety and efficacy end points. It is expected to be completed by November $2020 .^{41}$

\section{REMDECO-19}

It is a multicentric study which will collect retrospective data on the use of remdesivir in patients of COVID-19. ${ }^{42}$ 
The study will categorize the clinical progress of the patients on a 7 points ordinal scale on day 15 of treatment with remdesivir. The trial is expected to be completed by May 2020. ${ }^{42}$

\section{Clinical trials in China}

Two clinical trials among COVID-19 patients were also carried out in China from February 2020 to April 2020. One was carried out among hospitalized patients with mild to moderate COVID-19 symptoms $(n=308)$. The primary outcome of this study was time to clinical recovery (upto 28 days) which was defined as time from the initiation of study treatment until normalization of fever, respiratory rate, oxygen saturation on room air, and alleviation of cough for at least 2 hours, or live hospital discharge. However, this study was suspended as COVID-19 was controlled in China and candidates were not available for recruitment. ${ }^{43}$

The other trial in China was among hospitalized patients with severe COVID-19 $(n=237) .{ }^{44}$ The trial recruited patients with illness of less than 12 days duration in 10 hospitals of Wuhan and included 140 (59\%) men and 96 $(41 \%)$ women; median age 65 years IQR 56-71. The primary outcome in this study was time to clinical improvement (upto 28 days), defined as time from initiation of therapy until two-point improvement on a six-category ordinal scale of clinical status (from $1=$ discharged to $6=$ death) or live discharge. However, steep decline in the number of cases being reported from China have not allowed the researchers to recruit the original number of cases. Moreover, the researchers published their result and reported inconclusive findings. ${ }^{44}$ There was no difference in the primary outcome, i.e. time to clinical improvement among the remdesivir and placebo groups. Though patients who were treated early in their illness (disease duration less than 10 days) had faster improvement in the remdesivir group compared to placebo, it was not statistically significant. Adverse effects were reported in $66 \%$ patients receiving remdesivir compared to $64 \%$ receiving placebo. Remdesivir had to be stopped in $12 \%$ patients due to adverse effects. ${ }^{44}$

In addition to the on-going trials with remdesivir, many other drugs are being repurposed for COVID-19. Some of the other phase 3 trials registered with the U. S. national library of medicine currently recruiting candidates to evaluate investigational drugs for treatment and prophylaxis of COVID-19 have been given in the (Table 2). ${ }^{45}$

While remdesivir has promising evidence from preclinical studies and compassionate use, it has not shown unequivocal results convincingly in clinical trials. Though, remdesivir might be able to fight COVID-19, we should not get our hopes up too high before results of ongoing clinical trials are available.
Table 2: Some of the promising drugs in phase 3 clinical trial for COVID-19 registered with clinical trial.gov, U. S. National Library of Medicine, NIH.

\begin{tabular}{|c|c|}
\hline Drug & Trials \\
\hline Hydroxychloroquine & $\begin{array}{l}\text { Alberta Hope COVID-19 for } \\
\text { the prevention of severe } \\
\text { COVID-19 disease }\end{array}$ \\
\hline $\begin{array}{l}\text { Hydrochloroquine } \\
\text { and famotidine }\end{array}$ & $\begin{array}{l}\text { Multi-site adaptive trials } \\
\text { using hydroxychloroquine for } \\
\text { COVID-19 }\end{array}$ \\
\hline $\begin{array}{l}\text { Hydroxychloroquine } \\
\text { sulfate } 200 \text { MG Vs } \\
\text { lopinavir/ritonavir }\end{array}$ & $\begin{array}{l}\text { Efficacy of pragmatic same } \\
\text { day COVID-19 ring } \\
\text { prophylaxis for adult } \\
\text { individuals exposed to SARS- } \\
\text { CoV-2 in Switzerland }\end{array}$ \\
\hline $\begin{array}{l}\text { Hydroxychloroquine } \\
\text { vs placebo } \\
\text { lopinavir and } \\
\text { ritonavir vs placebo }\end{array}$ & $\begin{array}{l}\text { Chemoprophylaxis of SARS- } \\
\text { CoV-2 infection (COVID-19) } \\
\text { in exposed healthcare worker }\end{array}$ \\
\hline $\begin{array}{l}\text { Hydroxychloroquine } \\
\text { vs azithromycin }\end{array}$ & $\begin{array}{l}\text { Hydroxychloroquine vs } \\
\text { azithromycin for outpatients } \\
\text { in Utah with COVID-19 }\end{array}$ \\
\hline $\begin{array}{l}\text { Anakinra, } \\
\text { siltuximab and } \\
\text { tocilizumab }\end{array}$ & $\begin{array}{l}\text { Treatment of COVID- } \\
19 \text { patients with anti- } \\
\text { interleukin drugs }\end{array}$ \\
\hline Tocilizumab & $\begin{array}{l}\text { A study to evaluate the safety } \\
\text { and efficacy of tocilizumab in } \\
\text { patients with severe COVID- } \\
19 \text { pneumonia }\end{array}$ \\
\hline CD24Fc & $\begin{array}{l}\text { CD24Fc as a non-antiviral } \\
\text { immunomodulator } \\
\text { in COVID-19 treatment }\end{array}$ \\
\hline $\begin{array}{l}\text { Human } \\
\text { immunoglobulin }\end{array}$ & $\begin{array}{l}\text { Polyvalent immunoglobulin } \\
\text { in COVID-19 related ARDS }\end{array}$ \\
\hline BCG vaccine & $\begin{array}{l}\text { BCG vaccination to protect } \\
\text { healthcare workers } \\
\text { against COVID-19 }\end{array}$ \\
\hline IFX-1 & $\begin{array}{l}\text { Open-label, randomized study } \\
\text { of IFX-1 in patients with } \\
\text { severe COVID-19 pneumonia }\end{array}$ \\
\hline Sarilumab & $\begin{array}{l}\text { Evaluation of the efficacy and } \\
\text { safety of sarilumab in } \\
\text { hospitalized patients } \\
\text { with COVID-19 }\end{array}$ \\
\hline
\end{tabular}

Many critical questions need to be answered from these trials which group of patients are more likely to respond to treatment, the young or old, women and children or those with pre-existing conditions. How early should the treatment be started? What are the likely adverse effects? What are the contraindications to use of remdesivir? What is the risk-benefit ratio? And more importantly, can the world governments afford remdesivir for their population, if found beneficial?

\section{Funding: No funding sources \\ Conflict of interest: None declared \\ Ethical approval: Not required}




\section{REFERENCES}

1. Leonardi D, Polodori C, Polidori P. The healthcare and pharmaceutical vulnerability emerging from the new Coronavirus outbreak. Eur J Hosp Pharm. 2020;0:1-2.

2. Hui DS, Azhar IE, Madani TA, Ntoumi F, Kock R, Dar O. The continuing 2019-nCoV epidemic threat of novel coronaviruses to global health the latest 2019 novel coronavirus outbreak in Wuhan, China. Int $\mathbf{J}$ Infectious Diseases. 2020;91:264-6.

3. Wu Z, McGoogan JM. Characteristics of and Important Lessons from the Coronavirus Disease 2019 (COVID-19) Outbreak in China: Summary of a Report of 72314 Cases from the Chinese Center for Disease Control and Prevention. JAMA. 2020;323(13):1239-42.

4. WHO Director-General's opening remarks at the media briefing on COVID-19 - 3 March 2020 World Health Organization, March 3, 2020.

5. World Health Organization. Coronavirus (COVID19) Pandemic. Available at: https://www.who.int/emergencies/diseases/novelcoronavirus-2019.

6. Sheahan TP, Sims AC, Leist SR, Schafer A, Won J, Brown AJ, et al. Comparative therapeutic efficacy of remdesivir and combination lopinavir, ritonavir, and interferon beta against MERS-CoV. Nature Communications. 2020;11(1):1-4.

7. Chang YC, Tung YA, Lee KH, Chen TF, Hsiao YC, Chang HC, et al. Potential therapeutic agents for COVID-19 based on the analysis of protease and RNA polymerase docking.

8. Elfiky AA. Ribavirin, Remdesivir, Sofosbuvir, Galidesivir, and Tenofovir against SARS-CoV-2 RNA dependent RNA polymerase (RdRp): a molecular docking study. Life Sci. 2020;25:117592.

9. World Health Organization. "Solidarity" clinical trial for COVID-19 treatments. Available at: https://www.who.int/emergencies/diseases/novelcoronavirus-2019/global-research-on-novelcoronavirus-2019-ncov/solidarity-clinical-trial-forcovid-19-treatments.

10. Warren TK, Jordan R, Lo MK, Ray AS, Mackman RL, Soloveva V, et al. Therapeutic efficacy of the small molecule GS-5734 against Ebola virus in rhesus monkeys. Nature. 2016;531(7594):381-5.

11. Brown AJ, Won JJ, Graham RL, Dinnon KH, Sims AC, Feng JY, et al. Broad spectrum antiviral remdesivir inhibits human endemic and zoonotic delta coronaviruses with a highly divergent RNA dependent RNA polymerase. Antiviral Res. 2019;169:104541.

12. Warren TK, Siegel D, Hui HC, Doerffler E, Clarke MO, Chun K, et al. Discovery and Synthesis of GS5734, a Phosphoramidate Prodrug of a Pyrrolo [2, 1 f][triazin 4 amino] Adenine C-Nucleoside (GS 5734) for the Treatment of Ebola and Emerging Viruses. USAMRIID Ft Detrick United States; 2017.
13. Lo MK, Jordan R, Arvey A, Sudhamsu J, Ranjan SP, Hotard AL, et al. GS-5734 and its parent nucleoside analog inhibit Filo, Pneumo, and Paramyxoviruses. Scientific Reports. 2017;7:43395.

14. Mulangu S, Dodd LE, Davey RT, Mbaya TO, Proschan M, Mukadi D, et al. A randomized, controlled trial of Ebola virus disease therapeutics. New England J Med. 2019;381(24):2293-303.

15. Holshue ML, Bolt DC, Lindquist S, Lofy $\mathrm{KH}$, Wiesman J, Bruce H, et al. First case of 2019 novel coronavirus in the United States. New England $\mathbf{J}$ Med. 2020;382(19):1787-99.

16. Dijkman R, Jebbink MF, Gaunt E, Rossen JW, Templeton KE, Kuijpers TW, et al. The dominance of human coronavirus OC43 and NL63 infections in infants. J Clin Virology. 2012;53(2):135-9.

17. Falsey AR, Walsh EE, Hayden FG. Rhinovirus and coronavirus infection-associated hospitalizations among older adults. J Infectious Diseases. 2002;185(9):1338-41.

18. Wit DE, Doremalen VN, Falzarano D, Munster VJ. SARS and MERS: recent insights into emerging coronaviruses. Nature Reviews Microbiology. 2016;14(8):523.

19. Lai CC, Shih TP, Ko WC, Tang HJ, Hsueh PR. Severe acute respiratory syndrome coronavirus 2 (SARS-CoV-2) and corona virus disease-2019 (COVID-19): the epidemic and the challenges. Int $\mathbf{J}$ Antimicrobial Agents. 2020:105924.

20. Elfiky AA, Mahdy SM, Elshemey WM. Quantitative structure-activity relationship and molecular docking revealed a potency of anti-hepatitis $\mathrm{C}$ virus drugs against human corona viruses. J Med Virol. 2017;89:1040-7.

21. Ahn DG, Choi JK, Taylor DR, Oh JW. Biochemical characterization of a recombinant SARS coronavirus nsp12 RNA-dependent RNA polymerase capable of copying viral RNA templates. Archives Virology. 2012;157(11):2095-104.

22. Elfiky AA. Anti-HCV, nucleotide inhibitors, repurposing against COVID-19. Life Sci. 2020:117477.

23. Elfiky AA, Ismail AM. Molecular docking revealed the binding of nucleotide/side inhibitors to Zika viral polymerase solved structures. SAR QSAR Environmental Res. 2018;29(5):409-18.

24. Kirchdoerfer RN, Ward AB. Structure of the SARSCoVnsp12 polymerase bound to nsp7 and nsp8 cofactors. Nature Communications. 2019;10(1):1-9.

25. Subissi L, Posthuma CC, Collet A, Dobbe ZJC, Gorbalenya AE, Decroly E, et al. One severe acute respiratory syndrome coronavirus protein complex integrates processive RNA polymerase and exonuclease activities. Proceedings National Academy Sci. 2014;111(37):3900-9.

26. Tortorici MA, Veesler D. Structural insights into coronavirus entry. Advances Virus Res. 2019;105:93116.

27. Walls AC, Park YJ, Tortorici MA, Wall A, McGuire AT, Veesler D. Structure, function, and antigenicity 
of the SARS-CoV-2 spike glycoprotein. Cell. 2020; 181(2):281-96.

28. Millet JK, Whittaker GR. Host cell proteases: Critical determinants of coronavirus tropism and pathogenesis. Virus Res. 2015;202:120-34.

29. Gordon CJ, Tchesnokov EP, Feng JY, Porter DP, Gotte M. The anti-viral compound remdesivir potently inhibits RNA-dependent RNA polymerase from Middle East respiratory syndrome coronavirus. J Biological Chemistry. 2020;295(15):4773-9.

30. Agostini ML, Andres EL, Sims AC, Graham RL, Sheahan TP, Lu X, et al. Coronavirus susceptibility to the antiviral remdesivir (GS-5734) is mediated by the viral polymerase and the proofreading exoribonuclease. M Bio. 2018;9(2):e00221-18.

31. World Health Organization. WHO R and D Blueprint Ad-hoc Expert Consultation on clinical trials for Ebola Therapeutics. Available at: https://www.who. int/ebola/drc-2018/summaries-of-evidenceexperimental-therapeutics.pdf?ua $=1$. Accessed on 21 June 2020.

32. Woo PC, Lau SK, Huang Y, Yuen KY. Coronavirus diversity, phylogeny and interspecies jumping. Experimental Biology Med. 2009;234(10):1117-27.

33. Wang M, Cao R, Zhang L, Yang X, Liu J, Xu M, et al. Remdesivir and chloroquine effectively inhibit the recently emerged novel coronavirus $(2019-\mathrm{nCoV})$ in vitro. Cell Res. 2020;30(3):269-71.

34. Choy KT, Wong AY, Kaewpreedee P, Sia SF, Chen D, Hui KP, et al. Remdesivir, lopinavir, emetine, and homoharringtonine inhibit SARS-CoV-2 replication in vitro. Antiviral Res. 2020:104786.

35. Grein J, Ohmagari N, Shin D, Diaz G, Asperges E, Castagna A, et al. Compassionate use of remdesivir for patients with severe Covid-19. New England J Med. 2020;382:2327-36.

36. U.S National Librabry of Medical Clinical Trials Registry. Trial of Treatments for COVID-19 in Hospitalized Adults (discovery). Available at: https://clinicaltrials.gov/ct2/show/NCT04315948?ter $\mathrm{m}=\mathrm{NCT} 04315948 \&$ draw $=2 \&$ rank $=1$.

37. U.S National Library of Medical Clinical Trials Registry. Adaptive COVID-19 Treatment Trial (ACTT). Available at: https://clinicaltrials.gov/ct2/ show/NCT04280705?term=NCT04280705\&draw $=2$ \&rank=1. Accessed on 21 June 2020.

38. National Institute of Allergy and Infectious Diseases. NIH Clinical Trial Shows Remdesivir Accelerates Recovery from Advanced COVID-19. Available at: https://www.niaid.nih.gov/news-events/nih-clinicaltrial-shows-remdesivir-accelerates-recoveryadvanced-covid-19. Accessed on 21 June 2020.
39. U.S National Librabry of Medical Clinical Trials Registry. Study to Evaluate the Safety and Antiviral Activity of Remdesivir (GS-5734TM) in Participants with Severe Coronavirus Disease (COVID-19). Available at: https://clinicaltrials.gov/ct2/show/ NCT04292899?term $=$ NCT04292899\&draw $=2 \&$ rank $=1$. Accessed on 21 June 2020 .

40. U.S National Library of Medical Clinical Trials Registry. Study to evaluate the Safety and Antiviral Activity of Remdesivir (GS-5734) in Participants with Moderate Coronavirus Disease (COVID-190 Compared to Standard of Care Treatment. Available at: https://clinicaltrials.gov/ct2/show/NCT04292730 ?term $=$ NCT04292730\&draw $=2 \&$ rank $=1$. Accessed on 21 June 2020.

41. U.S National Library of Medical Clinical Trials Registry. Study to Evaluate the Safety and Antiviral Activity of Remdesivir (GS-5734 ${ }^{\mathrm{TM}}$ ) in Participants with Moderate Coronavirus Disease (COVID-19) Compared to Standard of Care Treatment. Available at: https://clinicaltrials.gov/ct2/show/NCT04321616 ?term $=$ NCT04321616\&draw $=2 \&$ rank $=1$. Accessed on 21 June 2020.

42. U.S National Library of Medical Clinical Trials Registry. Multicenter, Retrospective Study of the Effects of Remdesivir in the Treatment of Severe Covid-19 Infections (REMDECO-19). Available at: https://clinicaltrials.gov/ct2/show/NCT04365725?ter $\mathrm{m}=$ remdesivir\&draw $=6 \& \mathrm{rank}=3$. Accessed on 21 June 2020.

43. U.S National Library of Medical Clinical Trials Registry. A Trial of Remdesivir in Adults with Mild and Moderate COVID-19. Available at: https://clinicaltrials.gov/ct2/show/NCT04252664?ter $\mathrm{m}=$ remdesivir \&draw $=2 \&$ rank $=2$. Accessed on 21 June 2020.

44. Wang Y, Zhang D, Du G, Du R, Zhao J, Jin Y, et al. Remdesivir in adults with severe COVID-19: a randomized, double-blind, placebo-controlled, multicentre trial. Lancet. 2020;395:1569-78.

45. U.S National Library of Medical Clinical trials Registry. Recruiting Studies | COVID-19 | Phase 3. Available at: https://clinicaltrials.gov/ct2/results? cond=COVID-19\&Search=Apply\&recrs=a\&age_v= $\&$ gndr $=\&$ type $=\& r$ slt $=\&$ phase $=2$. Accessed on 21 June 2020.

Cite this article as: Ahsan M, Mallick AK. Is remdesivir the therapeutic answer for COVID-19: a review of current knowledge. Int J Basic Clin Pharmacol 2020;9:1462-8. 